\title{
Facile and sensitive spectrophotometric determination of carbosulfan in formulations and environmental samples
}

\author{
K. Suresh Kumar • K. Suvardhan • D. Rekha • \\ K. Kiran • G. Chalapathi Rao • B. Jayaraj • \\ K. Janardhanam $\cdot$ P. Chiranjeevi
}

Published online: 26 January 2008

(C) Springer Science + Business Media B.V. 2008

Erratum to: Environ Monit Assess (2007) 129:271-276

\section{DOI 10.1007/s10661-006-9360-0}

The original version of this article unfortunately contained a mistake. The presentation of Fig. 2 was incorrect. Structure of the bendiocarb was printed instead of carbosulfan. The correct version is given below.

The online version of the original article can be found at doi: 10.1007/s10661-006-9360-0.

K. Suresh Kumar $\cdot$ K. Suvardhan • D. Rekha

G. Chalapathi Rao $\cdot$ P. Chiranjeevi $(\bowtie)$

Environmental Monitoring Laboratory,

Department of Chemistry, S.V. University,

Tirupati 517502 AP, India

e-mail: chiranjeevi_sai@yahoo.co.in

K. Kiran $\cdot$ K. Janardhanam

Department of Environmental Sciences,

S.V. University, Tirupati 517502 AP, India

B. Jayaraj

Department of Mathematics,

S.V. University, Tirupati 517502 AP, India 
Fig. 2 Interactions of carbosulfan with coupling reagents

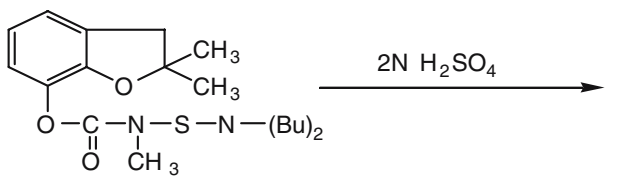

$$
\text { Carbosulfan }
$$<smiles>CNC(=O)Oc1cccc2c1OC(C)(C)C2</smiles>

Alkaline

hydrolysis

(2\% NaOH)<smiles>CC1(C)Cc2cccc(O)c2O1</smiles><smiles>[R]c1cc([R])c(N)c(F)c1</smiles>

$+\mathrm{NaNO}_{2}+\mathrm{HCl}+$

$\mathrm{R}$

Reagent

Hydrolysed product of Carbosulfan<smiles>CC1(C)Cc2cccc(O)c2O1</smiles><smiles>[R]c1cc([R])c(N=Nc2ccc(O)c3c2CC(C)(C)O3)c([R])c1</smiles>

$\mathrm{R}^{\prime}=\mathrm{Br}$

$\mathrm{R}=\mathrm{CH}_{3}$ or $\mathrm{NO}_{2}$ or $\mathrm{Br}$ 